\title{
Application of the Granuflow Process to Pipeline-Transported Coal Slurry CRADA PC96-010, Final Report
}

\author{
Richard P. Killmeyer \\ Wu-Wey Wen
}

September 24, 1997

U.S. Department of Energy

Federal Energy Technology Center

P.O. Box 10940

626 Cochrans Mill Road

Pittsburgh, PA 15236-0940

and

Williams Technologies, Inc.

320 South Boston

Suite 831

Tulsa, OK 74103-3718 


\section{Disclaimer}

This report was prepared as an account of work sponsored by an agency of the United States Government. Neither the United States Government nor any agency thereof, nor any of their employees, makes any warranty, express or implied, or assumes any legal liability or responsibility for the accuracy, completeness, or usefulness of any information, apparatus, product, or process disclosed, or represents that its use would not infringe privately owned rights. Reference herein to any specific commercial product, process, or service by trade name, trademark, manufacturer, or otherwise does not necessarily constitute or imply its endorsement, recommendation, or favoring by the United States Government or any agency thereof. The views and opinions of authors expressed herein do not necessarily state or reflect those of the United States Government or any agency thereof. 


\section{DISCLAIMER}

Portions of this document may be illegible in electronic image products. Images are produced from the best available original document. 


\section{BACKGROUND AND TECHNICAL OBJECTIVES}

In light of the current difficulties in processing fine coal and the potential for a significant increase in fines due to more demanding quality specifications, the U.S. Department of Energy's Federal Energy Technology Center (FETC) has been involved in the reconstitution of the fine clean coal resulting from advanced fine coal cleaning technologies. FETC has invented and developed a new strategy that combines fine-coal dewatering and reconstitution into one step. The process reduces the moisture content of the clean coal, and alleviates handling problems related to dustiness, stickiness, flowability, and freezing. This process has been named the GranuFlow Process.

Early work successfully demonstrated the feasibility of the process for laboratory-scale vacuum filtration dewatering using asphalt emulsion. These tests were focused on effects of mixing intensity, slurry temperature, asphalt emulsion composition, coal size, asphalt type and concentration, and drying procedure. The results indicated that the addition of asphalt to clean coal slurry improved filtration rate, reduced cake moisture, and significantly reduced the dustiness of the dried product.

Further tests focused on the application of the process to a screen-bowl centrifuge via short-term, batch mode tests at $300 \mathrm{lb} / \mathrm{hr}$. These tests produced roughly the same results as the laboratory filtration tests did, and they included some testing using Orimulsion, a bitumen emulsion. The Orimulsion seemed to offer greater potential for moisture reduction and was less affected by colder slurry temperatures.

Most recently, FETC has conducted several series of tests in its Coal Preparation Process Research Facility. These tests utilized a Sharples high g-force solid bowl centrifuge, and were run in a continuous mode at up to $450 \mathrm{lb} / \mathrm{hr}$ for as long as 6 hours. These tests dramatically showed the visible difference in the dewatered product by applying the GranuFlow Process, turning it from a clumpy, wet, sticky material into a granular, dry free-flowing product. In addition, it verified previous results with improvements in moisture content, dustiness, stickiness, and freezing. Orimulsion showed a significant benefit over asphalt emulsion in moisture reduction at additions more than $5 \%$.

The overall goal of this project was to successfully apply FETC's GranuFlow Process to improve coal slurry pipeline operations. Williams Technologies, Inc. (WTI), a leader in pipeline technology, has an interest in reducing the moisture content of the coal at the end of a coal slurry pipeline beyond what is being achieved with conventional mechanical dewatering teehnology. In addition, they would like to improve the handling characteristics of the dewatered coal. The GranuFlow Process has the potential of assisting in both of these areas, and its degree of applicability needed to be explored.

A formal Cooperative Research and Development Agreement (CRADA) between FETC and WTI was signed in November 1996. This CRADA consisted of 6 tasks progressing from preliminary scoping tests to a commercial field test, depending on the success of the testing. Task 1 was completed in February 1997, and it provided sufficient information about the 
applicability of the GranuFlow Process to coal slurry pipelines that further testing was not needed at the present time. Thus the CRADA was terminated. The information generated under Task 1 is Protected CRADA Information, and as such cannot be disclosed for a period of 3 years from the date the work was completed. 